Canadian University Music Review

Revue de musique des universités canadiennes

\title{
The Canadian Society for Eighteenth-Century Studies / Société canadienne d'étude du dix-huitième siècle: 14-18 October 1992
}

\section{Paul F. Rice}

Numéro 14, 1994

URI : https://id.erudit.org/iderudit/1014315ar

DOI : https://doi.org/10.7202/1014315ar

Aller au sommaire du numéro

Éditeur(s)

Canadian University Music Society / Société de musique des universités canadiennes

\section{ISSN}

0710-0353 (imprimé)

2291-2436 (numérique)

Découvrir la revue

Citer ce compte rendu

Rice, P. F. (1994). Compte rendu de [The Canadian Society for Eighteenth-Century Studies / Société canadienne d'étude du dix-huitième siècle: 14-18 October 1992]. Canadian University Music Review / Revue de musique des universités canadiennes, (14), 160-161.

https://doi.org/10.7202/1014315ar

All Rights Reserved (C Canadian University Music Society / Société de musique des universités canadiennes, 1994
Ce document est protégé par la loi sur le droit d'auteur. L'utilisation des services d'Érudit (y compris la reproduction) est assujettie à sa politique d'utilisation que vous pouvez consulter en ligne.

https://apropos.erudit.org/fr/usagers/politique-dutilisation/ 


\section{CONFERENCE REPORTS/ COMPTES RENDUS DE COLLOQUES}

\section{The Canadian Society for Eighteenth-Century Studies/Société canadienne d'étude du dix-huitième siècle 14-18 October 1992}

\section{Paul F. Rice}

The nineteenth meeting of the Canadian Society for Eighteenth-Century Studies/Société canadienne d'étude du dix-huitième siècle was held in the Hotel Newfoundland under the sponsorship of Memorial University of Newfoundland from 14-18 October 1992. This meeting of the society, organized by conference president Don Nichol and conference vice-president Margarete Smith, proved to be the largest to date. It was held in conjunction with the Atlantic Society for Eighteenth-Century Studies, and it welcomed, for the first time, members of the Canadian Society for the History of Medicine in a special session funded, in part, by the Canadian Federation for the Humanities. The conference attracted delegates from across Canada, the United States and the United Kingdom.

The conference theme, "New Worlds vs. Old: Discovery, Discourse \& Rediscovery in the 18th Century," permitted a wide range of topics to be presented which truly reflected the interdisciplinary nature of the society. A total of 145 papers were given, in addition to presentations by plenary speakers Roland Bonnel, Isobel Grundy and Pat Rogers. There were far too many memorable papers to list in this brief report; however, Isobel Grundy's plenary talk, "Medical Advance and Female Fame: inoculation and its after-effects," proved to be one of the highlights of the conference. Of related interest was the fascinating display of anatomical atlases set up in the Centre for Newfoundland Studies by Ken Roberts.

Two sessions of music papers were presented which featured David Schroeder (Dalhousie University) "Leopold Mozart's Projected Biography of his Famous Son," Glen Carruthers (Lakehead University) "Strangeness and Beauty: the opening measure of Mozart's Symphony in G minor, K. 550," John Eby (Bishop's University) "Was there a Requiem Mass composed for Louis XV?", Gordana Lazarevich (University of Victoria) "Beyond Commedia dell'arte: satireandcaricatureinthemid-eighteenth-century Italian comic musical theatre," Patricia Debly (Brock University) "Haydn and his Revision of his Opera 
Acide," and Paul F. Rice, "Rameau's Overtures." The School of Music at Memorial University of Newfoundland provided an evening concert of music by Haydn, Mozart and C.P.E. Bach that featured student and faculty performers. The society welcomes this interest in music, and the fine arts in general, and hopes that it will continue to grow and prosper in future meetings. In addition, the society publishes a select number of the conference papers in its journal, Lumen (formerly Man and Nature/L'homme et la nature).

It is with regret that I must report that the twentieth meeting of the society, scheduled to be held at Carleton University in October 1993, will be delayed until 13-16 October 1994, when it will be hosted by the University of Saskatchewan in Saskatoon. Although this delay will disappoint many, it will give the members of the society ample time to plan their papers. To that end, I should like to extend a special invitation to all whose interests lie in the fine and performing arts to consider submitting an abstract for the twentieth meeting of the society. The actual call for papers will be announced at a later time. Those interested in joining the society should contact Dr. Paul Wood, Department of History, University of Victoria, P.O. Box 3045, Victoria, British Columbia, V8W 3 P4.

\section{Actes du colloque « Musicologie historique et musicologie théorique : une coexistence est-elle possible ?" École de musique, Université Laval, Québec 5 mars 1993}

\section{Introduction}

L'École de musique de l'Université Laval a été l'hôte, au cours de l'après-midi du 5 mars 1993, d'un colloque portant sur la coexistence de deux types de musicologies : la musicologie historique et la musicologie théorique. L'organisateur du colloque, Marc-André Roberge, avait invité quatre musicologues représentant les deux tendances à venir présenter une prise de position de manière à lancer le débat entre les invités eux-mêmes et entre les invités et le public. Une bonne trentaine de personnes venant du Québec, de l'Ontario et du Nouveau-Brunswick, et dont plus de la moitié étaient des étudiants de deuxième et troisième cycles en musicologie, se sont réunies à la salle Henri-Gagnon du pavillon Louis-Jacques-Casault de l'Université Laval. 